\title{
Dietary calcium requirements of broilers fed a conventional corn-soybean meal diet from 1 to 21 days of age
}

Shiping Bai ${ }^{1,2,3 \dagger}$, Yunfeng Yang ${ }^{1 \dagger}$, Xuelian Ma ${ }^{1}$, Xiudong Liao ${ }^{1}$, Runlian Wang ${ }^{4}$, Liyang Zhang ${ }^{1}$, Sufen $\mathrm{Li}^{5}$, Xugang LuO ${ }^{2^{*}}$ and Lin Lu ${ }^{1 *}$

\begin{abstract}
Background: The current calcium (Ca) recommendation for broilers is primarily based on studies conducted more than 30 years ago with birds of markedly different productive potentials from those which exist today. And the response indicators in these studies are mainly growth performance and bone ash percentage. Therefore, the present study was carried out to investigate the effect of dietary Ca level on growth performance, serum parameters, bone characteristics and Ca metabolism-related gene expressions, so as to estimate dietary Ca requirements of broilers fed a conventional corn-soybean meal diet from 1 to 21 days of age.

Methods: A total of 420 1-day-old Arbor Acres male broilers were randomly assigned to 1 of 7 treatments with 6 replicates (10 birds per cage) and fed the corn-soybean meal diets containing 0.60\%, 0.70\%, 0.80\%, 0.90\%, 1.00\%, $1.10 \%$ or $1.20 \%$ Ca for 21 days. Each diet contained the constant non-phytate phosphorus content of about $0.39 \%$.

Results: The average daily gain decreased linearly $(P<0.001)$ as dietary Ca level increased. The serum and tibia alkaline phosphatase (ALP) activities, tibia bone mineral density (BMD), middle toe BMD, tibia ash percentage, tibia breaking strength, and tibia ALP protein expression level were affected $(P<0.05)$ by dietary Ca level, and showed significant quadratic responses $(P<0.02)$ to dietary $C a$ levels. The estimates of dietary Ca requirements were 0.80 to $1.00 \%$ based on the best fitted broken-line or quadratic models $(P<0.03)$ of the above serum and bone parameters, respectively.

Conclusions: The results from the present study indicate that the Ca requirements would be about $0.60 \%$ to obtain the best growth rate, and $1.00 \%$ to meet all of the Ca metabolisms and bone development of broilers fed a conventional corn-soybean meal diet from 1 to 21 days of age.
\end{abstract}

Keywords: Bone characteristic, Broiler, Calcium, Gene expression, Requirement

\footnotetext{
*Correspondence: wlysz@263.net; Iulin1225@163.com

†'Shiping Bai and Yunfeng Yang contributed equally to this work.

${ }^{2}$ Poultry Mineral Nutrition Laboratory, College of Animal Science and

Technology, Yangzhou University, Yangzhou 225000, China

${ }^{1}$ Mineral Nutrition Research Division, State Key Laboratory of Animal

Nutrition, Institute of Animal Science, Chinese Academy of Agricultural

Sciences, Beijing 100193, China

Full list of author information is available at the end of the article
}

C The Author(s). 2022 Open Access This article is licensed under a Creative Commons Attribution 4.0 International License, which permits use, sharing, adaptation, distribution and reproduction in any medium or format, as long as you give appropriate credit to the original author(s) and the source, provide a link to the Creative Commons licence, and indicate if changes were made. The images or other third party material in this article are included in the article's Creative Commons licence, unless indicated otherwise in a credit line to the material. If material is not included in the article's Creative Commons licence and your intended use is not permitted by statutory regulation or exceeds the permitted use, you will need to obtain permission directly from the copyright holder. To view a copy of this licence, visit http://creativecommons.org/licenses/by/4.0/ The Creative Commons Public Domain Dedication waiver (http://creativecommons.org/publicdomain/zero/1.0/) applies to the data made available in this article, unless otherwise stated in a credit line to the data. 


\section{Background}

Calcium (Ca) is an essential mineral element, and plays an important role in many biological processes, such as enzyme activation, intracellular signaling, acid-base balance and bone mineralization [1]. As about $99 \%$ of $\mathrm{Ca}$ is stored in skeleton as hydroxyapatite, $\mathrm{Ca}$ is crucial to the bone development of broilers [2]. Skeletal abnormalities attract great concern in poultry industry as they cause not only production problems but also considerable animal welfare issues. The deficiencies in content or improper ratios of $\mathrm{Ca}$ and phosphorus $(\mathrm{P})$ were usually considered as main nutritional reasons leading to greater incidences of leg abnormalities and huge economic loss [3].

The current $\mathrm{Ca}$ recommendations for broilers by NRC (1994) [4] were $1.00 \%, 0.90 \%$, and $0.80 \%$ for the starter ( 1 to $21 \mathrm{~d}$ ), grower ( 22 to $42 \mathrm{~d}$ ), and finisher (43 to $56 \mathrm{~d}$ ) phases, respectively. However, these recommendations are based on studies conducted in 1960s and 1980s [5, 6], and the response indicators in these studies are mainly growth performance and bone ash percentage. The modern broilers differ very much from those before 1980s in the growth rate, feed conversion efficiency, carcass quality and bone characteristics [7-9]. The feed efficiency of modern broiler chickens has been improved [7], and it is assumed that the feed intake has decreased, thus the modern broiler chickens have produced the same adequate bone traits with reduced $\mathrm{Ca}$. Therefore, the $\mathrm{Ca}$ requirements of modern fast-growing broilers might be different from those of broiler strains reared several decades ago. However, as $\mathrm{Ca}$ appears to be less threatening to the environment than $\mathrm{P}$ [10], and the sources of $\mathrm{Ca}$, namely limestone or oyster shell flour, are cheaper than other mineral sources, the determination of $\mathrm{Ca}$ requirements receives little attention [11]. It has also been reported that modern broilers have a high capacity to adapt $\mathrm{P}$ or $\mathrm{Ca}$ deficiency [12]. Nevertheless, the high level of dietary Ca may reduce the energy value of the diet and interferes with the availability of other minerals [13]. Decreasing the amount of dietary Ca may improve performance, but this should not be at the expense of increased leg problems [14]. Furthermore, the starter phase ( 1 to $21 \mathrm{~d}$ ) is a critical period for bone development of broilers. Thus it is necessary to re-evaluate dietary $\mathrm{Ca}$ requirements of broilers fed a conventional corn-soybean meal diet from 1 to 21 days of age.

Chicken bone mineral density (BMD) or content (BMC) determined by dual-emission X-ray absorptiometry (DEXA) was shown to be highly correlated with bone ash percentage, which could well reflect the Ca nutritional status [15]. Furthermore, the enzymes and proteins involved in Ca utilization were found sensitive to the dietary $\mathrm{Ca}$ levels in animals, especially alkaline phosphatase (ALP), osteocalcin (OC), osteoprotegerin (OPG), and bone morphogenetic protein-2 (BMP-2) were considered as good biological markers of bone metabolisms [16-19]. However, the above mentioned indicators have never been used to estimate dietary Ca requirements of chickens. We hypothesized that BMD, BMC and mRNA or protein expression levels of ALP, OC, OPG and BMP-2 in bone might be new sensitive indices to evaluate dietary $\mathrm{Ca}$ requirements of broilers fed a cornsoybean meal diet, and dietary $\mathrm{Ca}$ requirements of broilers from 1 to 21 days of age might be different from the current NRC Ca requirement (1.00\%).

Therefore, the objective of the current study was to investigate the impact of dietary Ca levels on growth performance, serum parameters, bone characteristics and Ca metabolism-related gene expressions of broilers, so as to choose sensitive indices to evaluate dietary $\mathrm{Ca}$ requirements of broilers fed a corn-soybean meal diet from 1 to 21 days of age.

\section{Materials and methods}

All experimental procedures were approved by the Animal Management Committee of the Institute of Animal Science, Chinese Academy of Agricultural Sciences (IAS-CAAS, Beijing, China), and performed in accordance with the guidelines. Ethical approval on animal survival was given by the animal ethics committee of IASCAAS. The ARRIVE guidelines were followed for reporting animal research [20].

\section{Experimental design, animals and diets}

A total of 420-day-old Arbor Acres male broiler chicks (Huadu Broiler Breeding Corp) with similar body weights were randomly allotted to 1 of 7 treatments with 6 replicate cages of 10 birds per cage in a completely randomized design, and housed in an electrically heated, thermostatically controlled room with fibreglass feeders, waterers and stainless-steel cages coated with plastics for $21 \mathrm{~d}$. They were maintained on a 24-h constant light schedule and allowed ad libitum access to experimental diets and tap water. The basal corn-soybean meal diet (Table 1) was formulated to meet or exceed the requirements $[4,21]$ of broilers for all other nutrients except for $\mathrm{Ca}$ and P. Dietary $\mathrm{Ca}$ levels for 7 treatments were calculated to be $0.60 \%, 0.70 \%, 0.80 \%, 0.90 \%, 1.00 \%$, $1.10 \%$ and $1.20 \% \mathrm{Ca}$, respectively. The requirement value of dietary non-phytate P (NPP) recommended by the current NRC [4] is $0.45 \%$. In the present study, each diet contained the constant NPP content of about $0.39 \%$ based on the results of our previous study [22]. A single large batch of the basal diet without limestone, was mixed at first, and then divided into 7 sublots according to the experimental treatment. Each sublot was mixed with limestone (containing $38.7 \%$ Ca by analysis) or fine sand [23, 24]. The washed fine sand containing no 
Table.1 Composition and nutrient levels of the basal diet for broilers from 1 to 21 days of age (as-fed basis)

\begin{tabular}{ll}
\hline Item & Contents \\
\hline Ingredients, \% & 52.97 \\
Corn & 37.51 \\
Soybean meal & 5.00 \\
Soybean oil & 1.72 \\
CaHPO $_{4}{ }^{a}$ & 0.24 \\
Limestone $^{\mathrm{a}}$ & 0.30 \\
Salt $^{\mathrm{a}}$ & 0.31 \\
DL-Met $^{\mathrm{a}}$ & 0.33 \\
Micronutrents $^{\mathrm{b}}$ & 1.62 \\
Sand & \\
Nutrient levels, \% & 12.69 \\
ME, MJ/kg & 21.62 \\
Crude protein $^{c}$ & 1.12 \\
Lysine & 0.59 \\
Methionine & 0.80 \\
Threonine & 0.23 \\
Tryptophane $_{\text {Methionine }+ \text { Cystine }}$ & 0.90 \\
Non-phytate phosphorus & 0.39 \\
Calcium $^{c}$ & 0.59 \\
\hline
\end{tabular}

${ }^{a}$ Feed grade

b Provided per kilogram of diet: VA, 15,000 IU; VD $4500 \mathrm{IU} ; \mathrm{VE}, 24 \mathrm{IU} ; \mathrm{VK}_{3}, 3$ $\mathrm{mg} ; \mathrm{VB}_{1}, 3 \mathrm{mg} ; \mathrm{VB}_{2}, 9.6 \mathrm{mg} ; \mathrm{VB}_{6}, 3 \mathrm{mg} ; \mathrm{VB}_{12}, 0.018 \mathrm{mg}$; Pantothenic acid calcium, $15 \mathrm{mg}$; Niacin, $39 \mathrm{mg}$; Folic acid, $1.5 \mathrm{mg}$; Biotin, $0.15 \mathrm{mg}$; Choline, 700 mg; $\mathrm{Zn}\left(\mathrm{ZnSO}_{4} .7 \mathrm{H}_{2} \mathrm{O}\right) 60 \mathrm{mg} ; \mathrm{Cu}\left(\mathrm{CuSO}_{4} \cdot 5 \mathrm{H}_{2} \mathrm{O}\right) 8 \mathrm{mg} ; \mathrm{Mn}\left(\mathrm{MnSO}_{4} \cdot \mathrm{H}_{2} \mathrm{O}\right) 110 \mathrm{mg}$; $\mathrm{Fe}\left(\mathrm{FeSO}_{4} \cdot 7 \mathrm{H}_{2} \mathrm{O}\right) 40 \mathrm{mg}$; I (KI) $0.35 \mathrm{mg} ; \mathrm{Se}\left(\left(\mathrm{Na}_{2} \mathrm{SeO}_{3}\right) 0.35 \mathrm{mg}\right.$

' Determined values based on triplicate measurements, and the others were calculated values

detectable $\mathrm{Ca}$ and $\mathrm{P}$ was used to maintain the same weight of each treatment diet. The dietary Ca levels by analysis on an as-fed basis were $0.59 \%, 0.70 \%, 0.80 \%$, $0.88 \%, 0.98 \%, 1.08 \%$ and $1.18 \%$, respectively. All diets were fed in mash form. At the end of the experiment, after fasting for 12-h, broiler weight and feed intake were recorded for each replicate cage and corrected for mortality to calculate average daily gain (ADG), average daily feed intake (ADFI) and feed: gain (FCR) from 1 to 21 days of age.

\section{Sample collections and preparations}

At the end of the experiment, chicks in each cage were individually weighed after fasting for 12 -h, and 12 chicks ( 2 chicks per cage) from each treatment were selected according to average body weight of each cage, respectively. Blood samples were promptly obtained using wing vein puncture, and then centrifuged to harvest serum and stored at $-20{ }^{\circ} \mathrm{C}$ for analyses of ALP activity and $\mathrm{Ca}$ or inorganic $\mathrm{P}$ contents. Birds were then killed by cervical dislocation. The left tibia and middle toe were collected and stored at $-20^{\circ} \mathrm{C}$ for analyses of bone characteristics. The right tibia was snap-frozen in liquid $\mathrm{N}_{2}$ and then stored at $-80^{\circ} \mathrm{C}$ for assays of ALP, BMP-2, OC or OPG mRNA and protein expression levels. To reduce individual biological variation, samples from two chickens in each replicate cage were pooled into one sample in equal ratios before analyses, and thus there were a total of 6 replicate samples for each treatment.

\section{Serum parameters}

Serum inorganic $\mathrm{P}$ was determined by vanadatemolybdate method [25]. Serum Ca and ALP activities in serum and tibia were measured using commercial assay kits (Nanjing Jiancheng Bioengineering Institute, Nanjing, China).

\section{Bone characteristics}

The frozen tibia and middle toe were thawed at room temperature for $2 \mathrm{~h}$, and BMC and BMD were determined by DEXA using the case of small animal model (Lunar_iDXA; GE healthcare, Madison, WI, USA). After the scan, tibia and middle toe were immediately rebagged and frozen until further analyses. The tibia bone strength was determined using a texture analyser (TA.XT plus; Stable Micro Systems, London, UK). The tibia was put on a fulcrum point with $50 \mathrm{~mm}$ apart. Loading point was located in the midpoint of fulcrum points. The value of breaking force was determined by the shear test at a speed of $5 \mathrm{~mm} / \mathrm{min}$ with a $50 \mathrm{~kg}$ loading cell until fracture occurred. The ultimate breaking force of the tibia was indirectly obtained, according to the load v. deformation curve recorded by computer. Following this testing, the tibia and middle toe were dried at $105^{\circ} \mathrm{C}$ for $24 \mathrm{~h}$ and defatted with fresh diethyl ether for $48 \mathrm{~h}$, and then dried at $105^{\circ} \mathrm{C}$ for $12 \mathrm{~h}$ to determine bone weight. The dried and defatted tibia and middle toe were ashed in muffle furnace at $550{ }^{\circ} \mathrm{C}$ for $24 \mathrm{~h}$ to measure bone ash weight and calculate bone ash percentage.

\section{Diet and bone ash analyses}

Samples of diets and bone ash were ground in a laboratory mill to pass through a $0.5 \mathrm{~mm}$ screen. The crude protein level in the basal diet was analyzed according to the Kjeldahl method [26]. The Ca concentrations in diets and bone ash were determined by inductively coupled plasma spectroscopy (Model IRIS Intrepid II; Thermo Jarrell Ash, Waltham, MA, USA). Total P concentrations in diets and bone ash were determined with a spectrophotometer [27]. Validations of $\mathrm{Ca}$ and total $\mathrm{P}$ analyses were conducted concurrently using soybean powder (GBW10013; National Institute of Standards and Technology, Beijing, China) as a standard reference material. 
RNA extraction and quantitative RT-PCR assays

The total RNA was isolated from the tibia by using TRIZOL reagent (Invitrogen Life Technologies, Carlsbad, CA, USA) according to the manufacturer's instructions. The concentration of total RNA was estimated by measuring its optical density at 260 and $280 \mathrm{~nm}$ with a spectrophotometer (ND-100; NanoDrop Technologies, Wilmington, DE, USA). A $500 \mathrm{ng}$ of total RNA was reversely transcribed into cDNA using PrimeScript ${ }^{\text {Tw }}$ RT Master Mix Kit (TaKaRa Bio Inc., Otsu, Japan) according to the manufacturer's instructions. The cDNA was used as templates for real-time quantitative PCR amplification using SYBR green master mix (Applied Biosystems, Foster City, CA, USA) on the ABI 7500 Real-Time PCR machine following the manufacturer's guidelines. The gene-specific primers for $A L P, B M P-2, O P G, O C$, $\beta$ actin and glyceraldehyde-3-phosphate dehydrogenase $(G A P D H)$ are shown in Table 2. Internal reference genes, both $\beta$-actin and GAPDH, were constant across the dietary treatment groups, and thus their geometric mean could be used to normalize the expression of the targeted gene [28]. Relative gene expression was calculated using the ${ }^{2-\Delta \Delta C t}$ method [29].

\section{Western blotting assays}

After ground in liquid $\mathrm{N}_{2}$, the tibia samples were homogenized in $0.5 \mathrm{~mL}$ of ice-cold radio immunoprecipitation assay lysis buffer (Beyotime Biotechnology, Haimen, China) supplemented with $5 \mu \mathrm{L}$ of protease inhibitor (BioTool, Houston, TX, USA). The homogenate was centrifuged at $10,000 \times g$ for $10 \mathrm{~min}$ at $4{ }^{\circ} \mathrm{C}$, and the supernatant was collected for total protein determination using a BCA Protein Assay Kit (Beyotime Biotechnology, Shanghai, China). The extracted protein $(20 \mu \mathrm{g})$ was subjected to electrophoresis on a $10 \%$ SDS-PAGE gel, and then electrotransferred onto the polyvinylidene fluoride membranes (Merck-Millipore, Munich, Germany). After the transfer, membranes were blocked for $1 \mathrm{~h}$ at room temperature in a blocking buffer with $5 \%$ non-fat milk, and then incubated overnight at $4{ }^{\circ} \mathrm{C}$ with the following primary antibodies: ALP (A6866; ABclonal, Wuhan, China), OPG (A135204; ABclonal, Wuhan, China), OC (A18241; ABclonal, Wuhan, China), BMP-2 (A0231; ABclonal, Wuhan, China) and $\beta$-tubulin (HX1829; Huaxingbio, Beijing, China). After washing, the membranes were incubated with the secondary antibody of goat anti-rabbit (HX2028; Huaxingbio, Beijing, China) or goat anti-mouse (HX2113; Huaxingbio, Beijing, China) for $1 \mathrm{~h}$ at room temperature. The signals were recorded with automatic chemiluminescence imaging analyzer (5200 Multi; Tanon, Shanghai, China) by Chemistar ECL Western Blotting Substrate (180-501; Tanon, Shanghai, China). Data were presented as the ratio of ALP, OPG, OC or BMP-2 protein band intensity to $\beta$-tubulin protein band intensity.

\section{Statistical analyses}

Data from the present study were subjected to one-way ANOVA using the general linear model procedure of SAS (v. 9.2, SAS Inst. Inc., Cary, NC, USA), and differences among means were tested by the least significant difference method. The replicate cage of 9 to 10 chickens for growth performance or two chickens for other indicators served as the experimental unit for all statistical analyses. Data from mortality were transformed to arcsine for analysis. Orthogonal comparisons were applied for linear and quadratic responses of dependent variables to independent variables. Regression analyses of broken-line, quadratic and asymptotic models were performed, and the best fitted models between

Table.2 Primer sequences for real-time PCR amplification

\begin{tabular}{|c|c|c|c|}
\hline Gene & GenBank ID & Primer sequences & Length, pb \\
\hline \multirow[t]{2}{*}{$\beta$-actin } & NM_205518.1 & F: 5'-ACCTGAGCGCAAGTACTCTGTCT-3' & 152 \\
\hline & & R: 5'-CATCGTACTCCTGCTTGCTGAT-3' & \\
\hline \multirow[t]{2}{*}{ GAPDH } & K01458 & F: 5'-CTTTGGCATTGTGGAGGGTC-3' & 128 \\
\hline & & R: 5'-ACGCTGGGATGATGTTCTGG-3' & \\
\hline \multirow[t]{2}{*}{ ALP } & NM_205360.1 & F: 5'-GGAGAAGGACCCCGAATACTG-3' & 300 \\
\hline & & R: 5'-TTGACGCCGCAGAGGTAAG-3' & \\
\hline \multirow[t]{2}{*}{ OPG } & XM_015283019.2 & F: 5'-ATCTCAGTCAAGTGGAGCATC-3' & 186 \\
\hline & & R: 5'-GTTCCAGTCTTCAGCGTAGTA-3' & \\
\hline \multirow[t]{2}{*}{ OC } & NM_205387.3 & F: 5'-TGCTCGCAGTGCTAAAGCCTTCAT-3' & 143 \\
\hline & & R: 5'-TCAGCTCACACACCTCTCGTT-3' & \\
\hline \multirow[t]{2}{*}{$B M P-2$} & NM_204358.1 & F: 5'-CCAACACCGTGTGCAGCTT-3' & 136 \\
\hline & & R: 5'-TGGAGTTCAGCTGAGGTGACAGA-3' & \\
\hline
\end{tabular}

${ }^{a}$ Abbreviations: GAPDH glyceraldehyde-3-phosphate dehydrogenase, $A L P$ alkaline phosphatase, $O P G$ osteoprotegerin, $O C$ osteocalcin, $B M P-2$ bone morphogenetic protein-2 
responsive criteria and dietary $\mathrm{Ca}$ level concentrations were used to determine dietary $\mathrm{Ca}$ requirements (the break point from broken-line model or the maximum response from quadratic model) of broilers [30]. The level of statistical significance was set at $P \leq 0.05$.

\section{Results}

\section{Growth performance and mortality}

Dietary Ca level affected $(P<0.005)$ body weight on $d$ 21 and ADG of broilers from 1 to 21 days of age, but did not affect $(P>0.10)$ ADFI, FCR and mortality (Table 3). The body weight on d 21 and ADG decreased linearly $(P<0.0001)$ as dietary $C a$ level increased. Broilers had the highest ADG at dietary Ca level of $0.59 \%$. Furthermore, all broilers did not show leg abnormality during the whole experimental period.

\section{Serum parameters and ALP activity in the tibia}

Dietary $C a$ level did not affect $(P>0.05)$ serum $C a$ and inorganic $\mathrm{P}$ contents, and $\mathrm{Ca}$ to inorganic $\mathrm{P}$ ratio of broilers (Table 4$)$, but affected $(P<0.05)$ ALP activities in serum and tibia. As dietary $\mathrm{Ca}$ level increased, the ALP activity in serum increased linearly $(P=0.0003)$ and quadratically $(P=0.002)$, and it in tibia decreased quadratically $(P=0.005)$. The minimum ALP activity in serum was observed at $0.98 \% \mathrm{Ca}$ level, and that in tibia at $0.80 \% \mathrm{Ca}$ level.

\section{Tibia characteristics}

Dietary Ca level did not affect $(P>0.39)$ tibia ash $C a$ or $\mathrm{P}$ contents and $\mathrm{Ca}$ to $\mathrm{P}$ ratio, but affected $(P<0.03)$ the tibia ash percentage, BMD, BMC and breaking strength (Table 5). As dietary $\mathrm{Ca}$ level increased, tibia ash percentage and BMD increased quadratically $(P<0.004)$, but tibia BMC increased linearly $(P=0.012)$. In addition, tibia breaking strength increased linearly $(P=0.001)$ and quadratically $(P=0.012)$ with increasing dietary $\mathrm{Ca}$ levels. Tibia ash percentage or breaking strength reached a plateau, and tibia BMD reached the highest point at $0.88 \% \mathrm{Ca}$.

\section{Middle toe characteristics}

Dietary Ca level did not influence $(P>0.11)$ the middle toe ash percentage, $\mathrm{P}$ content, $\mathrm{Ca}$ to $\mathrm{P}$ ratio and $\mathrm{BMC}$, but influenced $(P<0.009)$ its ash $\mathrm{Ca}$ content and BMD (Table 6). The middle toe ash $\mathrm{Ca}$ content increased linearly $(P<0.0001)$, but its BMD increased quadratically $(P<0.0001)$ as dietary $C a$ level increased. The highest middle toe BMD was observed visually at $0.88 \%$ dietary Ca level.

mRNA levels of ca metabolism-related genes in the tibia Dietary $C a$ level affected $(P<0.03)$ tibia $O C$ and $B M P-2$ mRNA expression levels, but did not affect $(P>0.30)$ tibia $A L P$ and $O P G$ mRNA expression levels (Table 7). As dietary $\mathrm{Ca}$ level increased, both $O C$ and $B M P-2$ mRNA levels decreased linearly $(P<0.03)$.

\section{Protein expression levels of ca metabolism-related genes in the tibia}

Dietary Ca level affected $(P=0.04)$ tibia ALP protein expression levels, but did not affect $(P>0.24)$ tibia OPG, OC and BMP-2 protein expression levels (Table 7). The tibia ALP protein expression level increased quadratically $(P=0.006)$ as dietary Ca level increased. The highest tibia ALP protein expression level was observed visually at $0.88 \%$ dietary $\mathrm{Ca}$ level.

Table.3 Effect of dietary calcium (Ca) level on the growth performance of broilers during 1 to $21 \mathrm{~d}$ of age 1

\begin{tabular}{|c|c|c|c|c|c|}
\hline Analyzed dietary Ca level, \% & Body weight on d 21, g & $A D F I, g / d$ & ADG, $g / d$ & FCR, $g / g$ & Mortality $^{2}, \%$ \\
\hline 0.59 & $825^{a}$ & 46.32 & $37.13^{\mathrm{a}}$ & 1.25 & 1.67 \\
\hline 0.70 & $793^{b}$ & 44.90 & $35.64^{\mathrm{b}}$ & 1.26 & 1.67 \\
\hline 0.80 & $781^{b c}$ & 44.43 & $35.09^{b c}$ & 1.27 & 3.33 \\
\hline 0.88 & $792^{b}$ & 44.98 & $35.58^{\mathrm{b}}$ & 1.26 & 0.00 \\
\hline 0.98 & $789^{b}$ & 44.83 & $35.46^{\mathrm{bc}}$ & 1.27 & 0.00 \\
\hline 1.09 & $768^{b c}$ & 43.83 & $34.46^{\mathrm{bc}}$ & 1.27 & 0.00 \\
\hline 1.18 & $757^{c}$ & 43.43 & $33.94^{c}$ & 1.28 & 0.00 \\
\hline SEM & 10.8 & 1.668 & 0.096 & 0.029 & 0.017 \\
\hline \multicolumn{6}{|l|}{$P$-value } \\
\hline Ca level & 0.004 & 0.11 & 0.004 & 0.71 & 0.33 \\
\hline Linear & $<0.0001$ & - & $<0.0001$ & - & - \\
\hline Quadratic & 0.72 & - & 0.72 & - & - \\
\hline
\end{tabular}

Data represented the means of 6 replicates $(n=6)$

${ }^{2}$ Mortality was based on analysis after anti-sine transform

${ }^{\mathrm{a}-\mathrm{c}}$ Means within a column with unlike superscript letters were significantly different $(P<0.05)$ 
Table.4 Effect of dietary calcium (Ca) level on serum parameters and tibia ALP activities of broilers on d $21^{1}$

\begin{tabular}{|c|c|c|c|c|c|}
\hline $\begin{array}{l}\text { Analyzed dietary } \\
\text { Ca level, \% }\end{array}$ & $\begin{array}{l}\text { Serum Ca content, } \\
\mathrm{mg} / 100 \mathrm{~mL}\end{array}$ & $\begin{array}{l}\text { Serum inorganic } P \text {, } \\
\mathrm{mg} / 100 \mathrm{~mL}\end{array}$ & $\begin{array}{l}\text { Serum Ca: } \\
\text { inorganic } \mathrm{P} \text { ratio }\end{array}$ & $\begin{array}{l}\text { Serum ALP Activity, King } \\
\text { unit/100 mL }\end{array}$ & $\begin{array}{l}\text { Tibia ALP Activity, King } \\
\text { unit/g prot }\end{array}$ \\
\hline 0.59 & 8.63 & 6.22 & 1.39 & $312^{\text {cd }}$ & $384^{a}$ \\
\hline 0.70 & 8.65 & 7.09 & 1.23 & $380^{b c}$ & $350^{\mathrm{ab}}$ \\
\hline 0.80 & 8.21 & 6.78 & 1.22 & $304^{\text {cd }}$ & $271^{c}$ \\
\hline 0.88 & 8.50 & 7.14 & 1.19 & $345^{\mathrm{bcd}}$ & $305^{b c}$ \\
\hline 0.98 & 8.95 & 6.92 & 1.30 & $294^{d}$ & $340^{\mathrm{ab}}$ \\
\hline 1.09 & 8.63 & 6.81 & 1.27 & $396^{b}$ & $348^{\mathrm{ab}}$ \\
\hline 1.18 & 8.76 & 6.36 & 1.39 & $486^{a}$ & $355^{\mathrm{ab}}$ \\
\hline SEM & 0.553 & 0.534 & 0.133 & 51.9 & 57.1 \\
\hline \multicolumn{6}{|l|}{$P$-value } \\
\hline Ca level & 0.43 & 0.06 & 0.08 & $<0.0001$ & 0.04 \\
\hline Linear & - & - & - & 0.0003 & 0.82 \\
\hline Quadratic & - & - & - & 0.002 & 0.005 \\
\hline
\end{tabular}

'Data represented the means of 6 replicates $(n=6)$

${ }^{2}$ Abbreviation: ALP alkaline phosphatase

${ }^{\mathrm{a}-\mathrm{d}}$ Means within a column with unlike superscript letters were significantly different $(P<0.05)$

\section{Estimations of dietary ca requirements of broilers}

Results of dietary $\mathrm{Ca}$ requirements of broilers as estimated by the non-linear regression analyses are shown in Table 8. The results indicate that serum and tibia ALP activities, tibia ash percentage, tibia breaking strength, tibia and middle toe BMD, and tibia ALP protein expression level were suitable criteria for evaluating dietary $\mathrm{Ca}$ requirements of broilers. Based on the best fitted broken-line or quadratic models of the above criteria, optimal dietary $\mathrm{Ca}$ levels were estimated to be $1.00 \%, 0.80 \%, 0.93 \%, 0.88 \%, 0.93 \%, 0.91 \%$ and $0.90 \%$ for broilers fed a conventional corn-soybean meal diet from 1 to 21 days of age. However, broilers had the highest ADG at dietary Ca level of $0.59 \%$. Therefore, in general, the $\mathrm{Ca}$ requirement would be about $0.60 \%$ to obtain the best growth rate and $1.00 \%$ to meet all of the Ca metabolisms and bone development of broilers fed a conventional corn-soybean meal diet from 1 to 21 days of age.

\section{Discussion}

Our hypotheses that BMD, BMC and mRNA or protein expression levels of ALP, OC, OPG and BMP-2 in bone might be new sensitive criteria to evaluate dietary Ca requirements of broilers fed a corn-soybean meal diet, and dietary Ca requirements of broilers from 1 to 21 days of age might be different from the current NRC Ca requirement $(1.00 \%)$ have been partially supported by the results of the current study. The current study indicated

Table.5 Effect of dietary calcium (Ca) level on tibia bone parameters of broilers on $\mathrm{d} 21^{1}$

\begin{tabular}{|c|c|c|c|c|c|c|c|}
\hline $\begin{array}{l}\text { Analyzed dietary Ca } \\
\text { level, \% }\end{array}$ & $\begin{array}{l}\text { Tibia ash } \\
\text { percentage, \% }\end{array}$ & $\begin{array}{l}\text { Tibia ash Ca } \\
\text { content, } \%\end{array}$ & $\begin{array}{l}\text { Tibia ash } \\
\mathrm{P}, \%\end{array}$ & $\begin{array}{l}\text { Tibia ash Ca: } \mathrm{P} \\
\text { ratio }\end{array}$ & $\begin{array}{l}\text { Tibia BMD, } \\
\mathrm{mg} / \mathrm{cm}^{2}\end{array}$ & $\begin{array}{l}\text { Tibia } \\
\text { BMC, } \mathbf{g}\end{array}$ & $\begin{array}{l}\text { Tibia breaking } \\
\text { strength, } \mathbf{N}\end{array}$ \\
\hline 0.59 & $49.3^{b c}$ & 35.1 & 17.8 & 1.96 & $136^{\mathrm{bc}}$ & $0.88^{\mathrm{b}}$ & $98^{c}$ \\
\hline 0.70 & $48.7^{c}$ & 35.3 & 17.9 & 1.97 & $133^{c}$ & $0.82^{b}$ & $109^{b c}$ \\
\hline 0.80 & $50.2^{a b}$ & 35.6 & 17.9 & 1.98 & $146^{b}$ & $0.98^{a b}$ & $129^{\mathrm{ab}}$ \\
\hline 0.88 & $50.9^{a}$ & 35.8 & 18.0 & 1.99 & $158^{a}$ & $1.00^{\mathrm{ab}}$ & $140^{a}$ \\
\hline 0.98 & $50.6^{a b}$ & 35.3 & 17.9 & 1.97 & $145^{b}$ & $1.02^{\mathrm{ab}}$ & $134^{\mathrm{ab}}$ \\
\hline 1.09 & $50.5^{\mathrm{ab}}$ & 35.6 & 17.9 & 1.99 & $141^{b c}$ & $1.10^{a}$ & $131^{\mathrm{ab}}$ \\
\hline 1.18 & $49.4^{\mathrm{abc}}$ & 35.6 & 17.6 & 2.03 & $142^{b c}$ & $0.95^{\mathrm{b}}$ & $132^{\mathrm{ab}}$ \\
\hline SEM & 1.17 & 0.79 & 0.34 & 0.052 & 8.0 & 0.105 & 19.7 \\
\hline \multicolumn{8}{|l|}{ P-value } \\
\hline Ca level & 0.004 & 0.73 & 0.40 & 0.45 & 0.0003 & 0.027 & 0.008 \\
\hline Linear & 0.07 & - & - & - & 0.11 & 0.012 & 0.001 \\
\hline Quadratic & 0.003 & - & - & - & 0.0006 & 0.052 & 0.012 \\
\hline
\end{tabular}

${ }^{1}$ Data represented the means of 6 replicates $(n=6)$

${ }^{2}$ Abbreviations: $B M C$ Bone mineral content, $B M D$ bone mineral density

${ }^{\mathrm{a}-\mathrm{c}}$ Means within a column with unlike superscript letters were significantly different $(P<0.05)$ 
Table.6 Effect of dietary calcium (Ca) level on middle toe bone parameters of broilers on $\mathrm{d} 21^{1}$

\begin{tabular}{|c|c|c|c|c|c|c|}
\hline Analyzed dietary Ca level, \% & Toe ash percentage, \% & Toe ash Ca, \% & Toe ash P, \% & Toe ash Ca: $\mathrm{P}$ ratio & Toe BMD, mg/cm² & Toe BMC, $\mathrm{g}$ \\
\hline 0.59 & 41.6 & $36.9^{c}$ & 17.99 & 2.04 & $45^{c}$ & 0.13 \\
\hline 0.70 & 41.2 & $37.2^{\mathrm{bc}}$ & 18.14 & 2.06 & $51^{\mathrm{bc}}$ & 0.15 \\
\hline 0.80 & 41.91 & $37.6^{\mathrm{abc}}$ & 18.22 & 2.10 & $55^{\mathrm{ab}}$ & 0.20 \\
\hline 0.88 & 42.1 & $37.6^{\mathrm{abc}}$ & 18.51 & 2.07 & $56^{\mathrm{a}}$ & 0.18 \\
\hline 0.98 & 41.9 & $37.8^{\mathrm{ab}}$ & 18.24 & 2.06 & $53^{\mathrm{ab}}$ & 0.18 \\
\hline 1.09 & 42.3 & $37.9^{\mathrm{a}}$ & 18.07 & 2.08 & $46^{c}$ & 0.15 \\
\hline 1.18 & 41.2 & $38.1^{\mathrm{a}}$ & 17.99 & 2.09 & $46^{c}$ & 0.17 \\
\hline SEM & 0.215 & 0.530 & 0.324 & 0.053 & 4.5 & 0.046 \\
\hline \multicolumn{7}{|l|}{$P$-value } \\
\hline Ca level & 0.20 & 0.008 & 0.12 & 0.52 & $<0.0001$ & 0.18 \\
\hline Linear & - & $<0.0001$ & - & - & 0.37 & - \\
\hline Quadratic & - & 0.55 & - & - & $<0.0001$ & - \\
\hline
\end{tabular}

${ }^{1}$ Data represented the means of 6 replicates $(n=6)$

${ }^{2}$ Abbreviations: $B M C$ bone mineral content, $B M D$ bone mineral density

${ }^{a-c}$ Means within a column with unlike superscript letters were significantly different $(P<0.05)$

that tibia and middle toe BMD, serum and tibia ALP activities, and tibia ALP protein level were new sensitive criteria to evaluate dietary $\mathrm{Ca}$ requirements of broilers, and the Ca requirement would be about $0.6 \%$ to obtain the best growth rate and $1.00 \%$ to meet all of the Ca metabolisms and bone development of broilers fed a conventional corn-soybean meal diet from 1 to 21 days of age. These findings could better characterize requirements and meet the growth, bone development and $\mathrm{Ca}$ metabolic functions of broilers.
In earlier studies, growth performance was often used to assess $\mathrm{Ca}$ requirements of broilers $[6,13]$. In order to maximize the growth performance of broilers, using diets with $0.6 \% \mathrm{Ca}$ becomes more widespread [2]. As birds possess specific $\mathrm{Ca}$ appetite [31], they get adapted to low $\mathrm{Ca}$ diets by increasing absorption and utilization efficiency, which decreases excretion of the restricted nutrients [12] and elevates plasma 1,25-dihydroxyvitamin $D_{3}$ $\left(1,25(\mathrm{OH})_{2} \mathrm{D}_{3}\right)$ concentration and duodenal calbindin concentrations $[32,33]$. The current study showed that

Table.7 Effect of dietary calcium (Ca) level on ALP, OPG, OC and BMP-2 mRNA and protein expression levels in the tibia of broilers on $\mathrm{d} 21^{1}$

\begin{tabular}{|c|c|c|c|c|c|c|c|c|}
\hline $\begin{array}{l}\text { Analyzed dietary Ca } \\
\text { level, \% }\end{array}$ & $\begin{array}{l}A L P \text { mRNA, } \\
\mathrm{RQ}^{2}\end{array}$ & $\begin{array}{l}\text { OPG mRNA, } \\
\mathrm{RQ}^{2}\end{array}$ & $\begin{array}{l}\text { OC mRNA, } \\
\mathrm{RQ}^{2}\end{array}$ & $\begin{array}{l}\text { BMP-2 mRNA, } \\
\mathrm{RQ}^{2}\end{array}$ & $\begin{array}{l}\text { ALP protein, } \\
\mathrm{RQ}^{3}\end{array}$ & $\begin{array}{l}\text { OPG protein, } \\
\mathrm{RQ}^{3}\end{array}$ & $\begin{array}{l}\text { OC protein, } \\
\mathrm{RQ}^{3}\end{array}$ & $\begin{array}{l}\text { BMP-2 } \\
\text { protein, } \mathrm{RQ}^{3}\end{array}$ \\
\hline 0.59 & 1.11 & 0.98 & $1.69^{a}$ & $0.91^{\mathrm{ab}}$ & $0.89^{c}$ & 1.14 & 1.75 & 1.03 \\
\hline 0.70 & 1.06 & 1.19 & $1.24^{\mathrm{ab}}$ & $1.07^{\mathrm{a}}$ & $1.03^{a b c}$ & 1.03 & 1.62 & 0.81 \\
\hline 0.80 & 0.84 & 0.97 & $0.85^{b c}$ & $0.72^{b c}$ & $1.17^{\mathrm{ab}}$ & 0.98 & 1.67 & 0.79 \\
\hline 0.88 & 0.89 & 0.85 & $1.00^{\mathrm{bc}}$ & $0.88^{a b c}$ & $1.19^{a}$ & 0.91 & 1.65 & 0.73 \\
\hline 0.98 & 1.00 & 1.00 & $1.00^{\mathrm{bc}}$ & $1.00^{\mathrm{ab}}$ & $1.06^{\mathrm{abc}}$ & 0.88 & 1.88 & 0.79 \\
\hline 1.09 & 0.87 & 0.74 & $0.65^{c}$ & $0.79^{a b c}$ & $0.95^{b c}$ & 1.03 & 1.58 & 0.85 \\
\hline 1.18 & 0.75 & 0.79 & $0.66^{c}$ & $0.66^{c}$ & $1.03^{a b c}$ & 1.01 & 1.43 & 0.89 \\
\hline SEM & 0.107 & 0.113 & 0.147 & 0.092 & 0.069 & 0.089 & 0.134 & 0.081 \\
\hline \multicolumn{9}{|l|}{$P$-value } \\
\hline Ca level & 0.37 & 0.31 & 0.002 & 0.02 & 0.04 & 0.49 & 0.37 & 0.25 \\
\hline Linear & - & - & $<0.0001$ & 0.02 & 0.75 & - & - & - \\
\hline Quadratic & - & - & 0.11 & 0.24 & 0.006 & - & - & - \\
\hline
\end{tabular}

${ }^{1}$ Data represented the means of 6 replicates $(n=6)$

${ }^{2}$ The mRNA levels were calculated as the relative quantity $(\mathrm{RQ})$ of the target gene mRNA to the geometric mean of $\beta$-actin and glyceraldehyde-3-phosphate dehydrogenase $\mathrm{mRNA}, \mathrm{RQ}=2^{-\Delta \Delta \mathrm{Ct}}(\mathrm{Ct}$, threshold cycle)

${ }^{3}$ The protein levels were calculated as the relative quantity $(\mathrm{RQ})$ of the target gene protein to the glyceraldehyde-3-phosphate dehydrogenase protein

${ }^{4}$ Abbreviations: $A L P$ alkaline phosphatase, BMP-2, morphogenetic protein-2, OC osteocalcin, OPG osteoprotegerin

${ }^{\mathrm{a}-\mathrm{c}}$ Means within a column with unlike superscript letters were significantly different $(P<0.04)$ 
Table.8 Estimations of dietary calcium (Ca) requirements of broilers from 1 to 21 days of age based on the best fitted broken-line or quadratic models

\begin{tabular}{|c|c|c|c|c|}
\hline Dependent variable & Regression equation $^{a}$ & $\mathrm{R}^{2}$ & $\begin{array}{l}P \text { - } \\
\text { value }\end{array}$ & $\begin{array}{l}\text { Dietary } \mathrm{Ca} \\
\text { requirements, \% }\end{array}$ \\
\hline Serum ALP activity & $Y_{1}=79.44-79.44 X(0.59 \leq X \leq 1.00) Y_{2}=-670.1+999.9 X(1.00 \leq X \leq 1.18)$ & 0.49 & $\begin{array}{l}< \\
0.0001\end{array}$ & 1.00 \\
\hline Tibia ash percentage & $\begin{array}{l}Y_{1}=44.895+6.5766 X(0.59 \leq X \leq 0.93) Y_{2}=-55.9373-5.3306 X(0.93 \leq X \leq \\
1.18)\end{array}$ & 0.29 & 0.005 & 0.93 \\
\hline Tibia ALP activity & $\begin{array}{l}Y_{1}=668.4286-473.9648 X(0.59 \leq X \leq 0.80) Y_{2}=134.7242+193.1789 X \\
(0.80 \leq X \leq 1.18)\end{array}$ & 0.27 & 0.007 & 0.80 \\
\hline Tibia breaking strength & $\begin{array}{l}Y_{1}=11.0110+145.1498 X(0.59 \leq X \leq 0.88) Y_{2}=162.1505-27.2524 X(0.88 \leq \\
X \leq 1.18)\end{array}$ & 0.37 & 0.0005 & 0.88 \\
\hline Tibia BMD & $Y=0.0285+0.2592 X-0.1400 X^{2}$ & 0.24 & 0.005 & 0.93 \\
\hline $\begin{array}{l}\text { Tibia ALP protein expression } \\
\text { level }\end{array}$ & $Y=-0.6983+4.0791 X-2.2713 X^{2}$ & 0.14 & 0.021 & 0.90 \\
\hline Middle toe BMD & $Y=-0.0341+0.2024 X-0.1153 X^{2}$ & 0.46 & $\begin{array}{l}< \\
0.0001\end{array}$ & 0.91 \\
\hline
\end{tabular}

a Regression equations based on the analyzed Ca concentrations (\%) in the diets

${ }^{\mathrm{b}}$ Abbreviations: $A L P$ alkaline phosphatase, $B M D$ bone mineral density

the increase of dietary Ca level from 0.70 to $1.18 \%$ had a negative impact on growth rate of broilers from 1 to 21 days. Similar results were reported by Walk et al. [9], indicating that the increase of dietary $\mathrm{Ca}$ level depressed the weight gain and feed intake at a $0.32 \%$ dietary NPP level. The possible reason for the negative effect of high$\mathrm{Ca}$ diet on broiler's growth rate might be due to that relatively high $\mathrm{Ca}$ reduced $\mathrm{P}$ availability [34], leading to the formation of extremely insoluble Ca-phytate complexes and severe $\mathrm{P}$ deficiency. In addition, higher dietary $\mathrm{Ca}$ could increase intestinal $\mathrm{pH}$, which reduced the absorptivity of minerals [35]. Hamdi et al. [13] found that broilers achieved their greatest weight gain with $0.70 \%$ dietary $\mathrm{Ca}$ and $0.38 \%$ dietary NPP. Additionally, some researchers recommended relatively lower levels of dietary $\mathrm{Ca}(0.60$ to $0.65 \%)$ for broilers according to weight gain and feed intake [36,37], which is similar to the results from the present study. However, Valable et al. [38] and Wilkinson et al. [39] reported that the reduction of dietary $\mathrm{Ca}$ did not affect the growth performance of broilers. Different breeds and growth phases of broilers might account for the discrepancy of the above results.

The $\mathrm{Ca}$ and $\mathrm{P}$ contents in serum and bone have been considered as good parameters to reflect the nutritional status of $\mathrm{Ca}$ in broilers $[40,41]$. However, the current study showed that dietary $\mathrm{Ca}$ level had no effect on serum and tibia $\mathrm{Ca}, \mathrm{P}$ content and $\mathrm{Ca}$ to $\mathrm{P}$ ratio, indicating that these parameters were not suitable to estimate the Ca requirements. Some researchers reported similar results [42, 43]. Hurwitz et al. [44] explained that modern broilers had good ability to keep serum $\mathrm{Ca}$ and $\mathrm{P}$ contents in narrow range regardless of the varying dietary Ca levels mainly because of the oscillations regulation system, in which parathyroid hormone, calcitonin and $1,25(\mathrm{OH})_{2} \mathrm{D}_{3}$ play an important role. In addition, the Ca content in middle toe ash increased linearly with increasing dietary $\mathrm{Ca}$ levels, indicating that middle toe ash $\mathrm{Ca}$ is not a useful marker for the assessment of $\mathrm{Ca}$ requirement of broilers.

Bone characteristics, such as bone ash percentage and breaking strength, have been traditional criteria to evaluate bone mineralization in broilers [22]. The NRC Ca recommendations for broilers were mainly based on maximizing bone ash. According to the results from the current study, the $\mathrm{Ca}$ requirements were $0.93 \%$ and $0.88 \%$ based on tibia ash percentage and breaking strength, respectively. And these two criteria increased quadratically as dietary $\mathrm{Ca}$ increased, which is in line with the results reported by Bar et al. [10]. However, some previous studies showed that the $\mathrm{Ca}$ requirement (1.3\%) based on bone ash contents of 21-d-old broilers was higher than the current $\mathrm{NRC} \mathrm{Ca}$ requirement $(1.00 \%)[6,45]$, which might be due to the high dietary P levels (from 0.7 to $0.75 \%$ ) in these studies. Shafey [46] reported that increasing dietary $\mathrm{Ca}$ enhanced the breaking strength of cockerel tibia. However, Onyango et al. [15] did not observe the same phenomenon, and thought that the high variability in breaking strength contributed to the lack of statistical significance. Actually, several factors can affect breaking strength, such as cross head speed, handling of bones before testing and measurement technique $[15,47,48]$. Some researchers determined BMC and BMD of broilers using DEXA $[49,50]$. The DEXA technology provided a rapid and noninvasive advantage measurement of bone mineralization compared with traditional measurement. Yan et al. [12] found that BMC and BMD were good indicators for $\mathrm{Ca}$ nutrition estimation. Onyango et al. [15] and Valable et al. [38] reported that BMC and BMD showed a linear 
and quadratic increase with the increase of dietary $\mathrm{Ca}$ level, which is similar to the results from the present experiment. The optimal Ca level was estimated to be $0.93 \%$ and $0.91 \%$ based upon tibia and middle toe BMD, which was close to that $(0.93 \%)$ estimated by the tibia ash percentage. Onyango et al. [15] showed that there was a high correlation between bone ash and BMC or $\mathrm{BMD}$. The above results indicate that the requirement for maximizing bone development was greater than that for the best growth performance of broilers, which was further confirmed by Bar et al. [10]. It might be viable to reduce the dietary $\mathrm{Ca}$ level in order to maximize the growth performance of broilers, however, it should not be at the expense of bone health.

Alkaline phosphatase is a ubiquitous enzyme that catalyzes the hydrolysis of phosphate monoesters [51], and can be used as a general indicator of skeletal development [52]. The increase of ALP activity is usually associated with inadequate supply of $\mathrm{Ca}$ or $\mathrm{P}$ and poor bone mineralization [53, 54]. Xia et al. [55] found that serum ALP activity was sensitive to the dietary $\mathrm{Ca}$, and can be used to evaluate the dietary $\mathrm{Ca}$ requirements for laying Longyan shelducks. The current study showed that both serum and tibia ALP activities changed quadratically as dietary Ca increased, and the Ca requirements to obtain the minimum ALP activities in serum and tibia were $1.00 \%$ and $0.80 \%$, respectively. Similarly, Hurwitz and Griminger [56] reported that serum ALP activity decreased as dietary $\mathrm{Ca}$ increased, reaching a minimum in the range of probable Ca requirement, and could be used as an indicator to evaluate $\mathrm{Ca}$ adequacy in growing chicks. In the present study, the tibia ALP protein expression level increased quadratically as dietary Ca increased, and the Ca requirement obtained from this indicator was $0.90 \%$, while the tibia $A L P$ mRNA expression level was not affected by dietary Ca. Mehra et al. [57] explained that changes in protein levels were not directly related to changes in mRNA levels, because of the complexity of transcription, translation and posttranslational modification. Another consideration might be the time course of the experiment. The tibia ALP mRNA may have been upregulated early in the study in response to dietary treatments, and by the end of the study, its expression levels may have returned to baseline values.

Bone metabolism includes bone formation and resorption. Markers of bone formation and resorption act as key determinants in the regulation of bone mass [17, 58]. Osteocalcin is the most abundant non-collagenous protein of bone matrix and plays an important role in the bone formation and Ca metabolism [59]. Osteoprotegerin is a secreted protein involved in the regulation of bone resorption $[58,60]$. The decrease of $O P G$ mRNA expression in the tibia led to the osteoporosis in broilers [61]. Jiang et al. [19] reported that the increase of dietary $\mathrm{Ca}$ level enhanced OPG mRNA and OC protein expression levels in the keel bone of hens. However, in the present study, dietary Ca levels did not affect $O P G$ mRNA and OC protein expression levels in the tibia of broilers. The disparity may mainly result from the different animal species (previous hens vs. present broilers) and bone samples. The BMP-2, a potent osteogenic differentiation factor, is essential for osteoblast differentiation and bone formation [62]. Jia et al. [63] found that the mRNA and protein levels of BMP-2 increased with increasing $\mathrm{Ca}^{2+}$ concentrations in the primary renal tubular epithelial cells. A study with piglets demonstrated that the serum BMP-2 concentration exhibited a trend from rise to decline with increasing dietary $\mathrm{Ca}$ levels [64]. Similar tendency was observed for the tibia $B M P-2$ mRNA levels as dietary Ca levels increased in the present study. In addition, the results from the present study showed that as dietary $\mathrm{Ca}$ levels increased, the tibia $O C$ and $B M P-2$ mRNA levels changed linearly, but not quadratically, indicating that these parameters are not suitable to estimate the requirements of $\mathrm{Ca}$ in broilers. We also found that the mRNA levels of $O C$ and $B M P-2$ in the tibia varied, while their protein levels did not change as dietary $\mathrm{Ca}$ levels increased, implying that the transcriptional change would often precede the translational change [60, 65].

The present study showed that the $\mathrm{Ca}$ requirement was $0.59 \%$ based on ADG. Similarly, Sebastian et al. [36] found that the optimum body weight, feed intake, and feed efficiency were obtained at $0.60 \%$ dietary Ca. We also found that the Ca requirements of broilers ranged from 0.8 to $1.00 \%$ based on tibia and middle toe characteristics, serum or tibia ALP activity, and tibia ALP protein expression level. In order to meet all of $\mathrm{Ca}$ metabolisms and bone development functions, dietary Ca requirement would be $1.00 \%$ for broilers fed a conventional corn-soybean meal diet from 1 to 21 days of age, which is in line with the current NRC Ca requirement. Previous reports suggested that the Ca requirement should be higher for skeletal development than for optimal growth $[10,66]$. Our findings also suggest that the current NRC (1994) recommendation for Ca (1.00\%) would be adequate for the optimum bone development but excessive for the best growth rate.

\section{Conclusions}

The results from the present study indicate that $0.59 \%$ dietary Ca level was sufficient to obtain the best growth rate of broilers form 1 to 21 days of age. However, considering the serum and tibia ALP activities, tibia ash and breaking strength, tibia and middle toe BMD, and tibia ALP protein expression level, the Ca requirement of broilers would be $1.00 \%$ to support all of the Ca metabolisms and skeletal development, which is the same as the current NRC Ca requirement. 


\section{Abbreviations}

ADFI: Average daily feed intake; ADG: Average daily gain; ALP: Alkaline phosphatase; BMC: Bone mineral concentration; BMD: Bone mineral density; BMP-2: Bone morphogenetic protein-2; Ca: Calcium; DEXA: Dual-emission Xray absorptiometry; $1,25(\mathrm{OH})_{2} \mathrm{D}_{3}$ : 1,25-dihydroxyvitamin $\mathrm{D}_{3} ; \mathrm{GAPD}$ H: Glyceraldehyde-3-phosphate dehydrogenase; IAS-CAAS: Institute of Animal Science, Chinese Academy of Agricultural Sciences; NPP: Non-phytate phosphorus; OC: Osteocalcin; OPG: Osteoprotegerin; P: Phosphorus

\section{Acknowledgements}

The authors gratefully acknowledge all professors and students in the mineral nutrition research division.

\section{Authors' contributions}

SB: methodology, data curation, writing-review and editing. YY: investigation, writing-original draft preparation. XM: investigation, data curation. XL: validation, software. RW: writing-review and editing. LZ: project administration. SL: resources. $\mathrm{XL}$ and $\mathrm{LL}$ : supervision, writing-review and editing, funding acquisition. All authors read and approved the final manuscript.

\section{Funding}

The present study was financially supported by the China Agriculture Research System of MOF and MARA (project number CARS-41; Beijing, P. R. China) and the Agricultural Science and Technology Innovation Program (ASTIP-IAS09; Beijing, P. R. China).

\section{Availability of data and materials}

The data are shown in the main manuscript.

\section{Declarations}

\section{Ethics approval and consent to participate}

The experimental protocols used in this experiment, including animal care and use, were reviewed and approved by the Animal Care and Use Ethics Committee of the Institute of Animal Science, Chinese Academy of Agricultural Sciences (Beijing, China).

\section{Consent for publication}

Not applicable.

\section{Competing interests}

The authors declare that they have no competing interests.

\begin{abstract}
Author details
${ }^{1}$ Mineral Nutrition Research Division, State Key Laboratory of Animal Nutrition, Institute of Animal Science, Chinese Academy of Agricultural Sciences, Beijing 100193, China. ${ }^{2}$ Poultry Mineral Nutrition Laboratory, College of Animal Science and Technology, Yangzhou University, Yangzhou 225000, China. ${ }^{3}$ Institute of Animal Nutrition, Sichuan Agricultural University, Chengdu 611130, Sichuan, China. ${ }^{4}$ Department of Animal Science, Guangdong Ocean University, Zhanjiang 524088, China. ${ }^{5}$ Department of Animal Science, Hebei Normal University of Science and Technology, Qinhuangdao 066004, China.
\end{abstract}

Received: 17 September 2021 Accepted: 16 November 2021 Published online: 03 February 2022

\section{References}

1. Li XH, Zhang DG, Bryden WL. Calcium and phosphorus metabolism and nutrition of poultry: are current diets formulated in excess? Anim Prod Sci. 2017:57(11):2304-10. https://doi.org/10.1071/AN17389.

2. Proszkowiec-Weglarz M, Angel R. Calcium and phosphorus metabolism in broilers: effect of homeostatic mechanism on calcium and phosphorus digestibility. J Appl Poult Res. 2013;22(3):609-27. https://doi.org/10.3382/ja pr.2012-00743.

3. Xie MS, Wang SX, Hou SS, Huang W. Interaction between dietary calcium and non-phytate phosphorus on growth performance and bone ash in early white Pekin ducklings. Anim Feed Sci Technol. 2009;151(1-2):161-6. https://doi.org/10.1016/j.anifeedsci.2009.01.005.

4. NRC. Nutrient requirements of poultry. 9th ed. Washington, DC: National Academy Press; 1994.
5. Twining PF, Lillie RJ, Robel EJ, Denton CA. Calcium and phosphorus requirements of broiler chickens. Poult Sci. 1965;44(1):283-96. https://doi. org/10.3382/ps.0440283.

6. Yoshida M, Hoshii $\mathrm{H}$. Re-evaluation of requirement of calcium and available phosphorus for starting meat-type chicks. Jap Poult Sci. 1982;19(2):101-9. https://doi.org/10.2141/jpsa.19.101.

7. Driver JP, Pesti GM, Bakalli RI, Edwards HM Jr. Calcium requirements of the 504 modern broiler chicken as influenced by dietary protein and age. Poult Sci. 2005;84(10):1629-39. https://doi.org/10.1093/ps/84.10.1629.

8. Havenstein G, Ferket P, Qureshi M. Carcass composition and yield of 1957 versus 2001 broilers when fed representative 1957 and 2001 broiler diets. Poult Sci. 2003;82(10):1509-18. https://doi.org/10.1093/ps/82.10.1509.

9. Walk CL, Addo-Chidie EK, Bedford MR, Adeola O. Evaluation of a highly soluble calcium source and phytase in the diets of broiler chickens. Poult Sci. 2012;91(9):2255-6. https://doi.org/10.3382/ps.2012-02224.

10. Bar A, Shinder S, Yosefi S, Vax E, Plavnik I. Metabolism and requirements for calcium and phosphorus in the fast-growing chicken as affected by age. $\mathrm{Br}$ J Nutr. 2003;89(1):51-61. https://doi.org/10.1079/BJN2002757.

11. Powell S, Bidner TD, Southern LL. Phytase supplementation improved growth performance and bone characteristics in broilers fed varying levels of dietary calcium. Poult Sci. 2011;90(3):604-8. https://doi.org/10.3382/ps.201 0-01000.

12. Yan F, Angel R, Ashwell C, Mitchell A, Christman M. Evaluation of the broiler's ability to adapt to an early moderate deficiency of phosphorus and calcium. Poult Sci. 2005;84(8):1232-41. https://doi.org/10.1093/ps/84. 8.1232.

13. Hamdi M, L'opez-Verg'e S, Manzanilla EG, Barroeta AC, P'erez JF. Effect of different levels of calcium and phosphorus and their interaction on the performance of young broilers. Poult Sci. 2015;94(9):2144-51. https://doi. org/10.3382/ps/pev177.

14. Coto CA, Yan F, Cerrate S, Wang Z, Sacakli P, Waldroupet PW, et al. Effects of dietary levels of calcium and nonphytate phosphorus in broiler starter diets on total and water-soluble phosphorus excretion as influenced by phytase and addition of 25-hydroxycholecalciferol. Int J Poult Sci. 2007; 12(12):937-43. https://doi.org/10.3923/ijps.2007.937.943.

15. Onyango EM, Hester PY, Stroshine R, Adeola O. Bone densitometry as an indicator of percentage tibia ash in broiler chicks fed varying dietary calcium and phosphorus levels. Poult Sci. 2003;82(11):1787-91. https://doi. org/10.1093/ps/82.11.1787.

16. Scott $D$. Factors affecting urinary pyridine line and deoxypyridino line excretion in the growing lamb. Bone. 1993;6(6):807-11. https://doi.org/10.1 016/8756-3282(93)90308-W.

17. Alexandrakis MG, Passam FH, Malliaraki N, Katachanakis C, Kyriakou DS, Margioris AN. Evaluation of bone disease in multiple myeloma: a correlation between biochemical markers of bone metabolism and other clinical parameters in untreated multiple myeloma patients. Clin Chim Acta. 2002; 325(1-2):51-7. https://doi.org/10.1016/S0009-8981(02)00246-2.

18. Silvestrini G, Ballanti P, Patacchioli F, Leopizzi M, Gualtieri N, Monnazzi P, et al. Detection of osteoprotegerin (OPG) and its ligand (RANKL) mRNA and protein in femur and tibia of the rat. J Mol Histol. 2005;36(1-2):59-67. https://doi.org/10.1007/s10735-004-3839-1.

19. Jiang S, Cui L, Shi C, Ke X, Luo J, Hou J. Effects of dietary energy and calcium levels on performance, egg shell quality and bone metabolism in hens. Vet J. 2013;198(1):252-8. https://doi.org/10.1016/j.tvjl.2013.07.017.

20. Kilkenny C, Browne WJ, Cuthi I. Improving bioscience research reporting: the ARRIVE guidelines for reporting animal research. Vet Clin Pathol. 2012; 41(1):27-31. https://doi.org/10.1111/j.1939-165X.2012.00418.x.

21. Ministry of Agriculture of P. R. China. Feeding standard of chicken (NY/T 332004). Beijing: China Agricultural Press; 2004.

22. Liu SB, Liao XD, Lu L, Li S, Wang L, Zhang L, et al. Dietary non-phytate phosphorus requirement of broilers fed a conventional corn-soybean meal diet from 1 to $21 \mathrm{~d}$ of age. Poult Sci. 2017;96(1):151-9. https://doi.org/10.33 82/ps/pew212.

23. Waldroup PW, Kersey JH, Saleh EA, Fritts CA, Yan F, Stilborn HL, et al. Nonphytate phosphorus requirement and phosphorus excretion of broiler chicks fed diets composed of normal or high available phosphate corn with and without microbial phytase. Poult Sci. 2000;79(10):1451-9. https://doi. org/10.1093/ps/79.10.1451.

24. Yan F, Kersey JH, Waldroup PW. Phosphorus requirements of broiler chicks three to six weeks of age as influenced by phytase supplementation. Poult Sci. 2001;80(4):455-9. https://doi.org/10.1093/ps/80.4.455. 
25. Gomori G. Modification of the colorimetric phosphorus determination for use with photometric colorimeter. J Lab Clin Med. 1942;27:955-66.

26. Thiex NJ, Manson H, Anderson S, Persson JA. Determination of crude protein in animal feed, forage, grain, and oilseeds by using block digestion with a copper catalyst and steam distillation into boric acid: collaborative study. J AOAC Int. 2002;85(2):309-17. https://doi.org/10.1093/jaoac/85.2.309.

27. Association of Official Analytical Chemists (AOAC). Official methods of analysis. 17th ed. Arlington: Association of AnalyticalCommunities; 2000

28. Sun $X M$, Liao $X D$, Lu L, Zhang $L Y, M a Q G$, Xi L, et al. Effect of in ovo zinc injection on the embryonic development, tissue zinc contents, antioxidation, and related gene expressions of broiler breeder eggs. J Integr Agr. 2018;17(3):648-56. https://doi.org/10.1016/S2095-3119(17)61704-0.

29. Cao S, Zhang S, Liu G, Zhang L, Lu L, Zhang R, et al. Kinetics of phosphorus absorption and expressions of related transporters in primary cultured duodenal epithelial cells of chick embryos. J Anim Physiol An N. 2020;104(1): 237-44. https://doi.org/10.1111/jpn.13260.

30. Ma XY, Liao XD, Lu L, Li SF, Zhang LY, Luo XG. Determination of dietary iron requirements by full expression of iron-containing enzymes in various tissues of broilers. J Nutr. 2016;146(11):2267-73. https://doi.org/10.3945/jn.11 6.237750.

31. Wilkinson SJ, Selle PH, Bedford MR, Cowieson AJ. Separate feeding of calcium improves performance and ileal nutrient digestibility in broiler chicks. Anim Prod Sci. 2014a;54(2):172-8. https://doi.org/10.1071/A N12432.

32. Morrissey RL, Wasserman RH. Calcium absorption and calcium-binding protein in chicks on differing calcium and phosphorus intakes. Am J Phys. 1971;220(5):1509-15. https://doi.org/10.1152/ajplegacy.1971.220.5.1509.

33. Bar A, Hurwitz S. Vitamin D metabolism and calbindin (calcium binding protein) in aged laying hens. J Nutr. 1987;117(10):1775-9. https://doi.org/1 0.1093/jn/117.10.1775.

34. Qian H, Kornegay ET, Denbow DM. Phosphorus equivalence of microbial phytase in Turkey diets as influenced by calcium to phosphorus ratios and phosphorus levels. Poult Sci. 1996;75(1):69-81. https://doi.org/10.3382/ps. 0750069.

35. Shafey TM, McDonald MW. The effects of dietary calcium, phosphorus, and protein on the performance and nutrient utilization of broiler chickens. Poult Sci. 1991;70(3):548-53. https://doi.org/10.3382/ps.0700548.

36. Sebastian S, Touchburn SP, Chavez ER, Lague PC. Efficacy of supplemental microbial phytase at different dietary calcium levels on growth performance and mineral utilization of broiler chickens. Poult Sci. 1996;75(12):1516-23. https://doi.org/10.3382/ps.0751516.

37. Sohail SS, Roland SR. Influence of supplemental phytase on performance of broilers four to six weeks of age. Poult Sci. 1999;78(4):550-5. https://doi. org/10.1093/ps/78.4.550.

38. Valable AS, Narcy A, Duclos MJ, Pomar C, Page G, Nasir Z, et al. Effects of dietary calcium and phosphorus deficiency and subsequent recovery on broiler chicken growth performance and bone characteristics. Animal. 2018; 12(8):1555-63. https://doi.org/10.1017/S1751731117003093

39. Wilkinson SJ, Bradbury EJ, Bedford MR, Cowieson AJ. Effect of dietary nonphytate phosphorus and calcium concentration on calcium appetite of broiler chicks. Poult Sci. 2014b;93(7):1695-703. https://doi.org/10.3382/ps.2 013-03537.

40. Shafey TM, McDonald MW, Pym RAE. Effects of dietary calcium, available phosphorus and vitamin $\mathrm{d}$ on growth rate, food utilisation, plasma and bone constituents and calcium and phosphorus retention of commercial broiler strains. Brit Poult Sci. 1990;31(3):587-602. https://doi.org/10.1080/ 00071669008417290

41. Hassanabadi A, Alizadeh-Ghamsari A, Leslie MA. Effects of dietary phytase, calcium and phosphorus on performance, nutrient utilization and blood parameters of male broiler chickens. J Anim Vet Adv. 2007;6: 1434-42.

42. Hulan HW, De Groote G, Fontaine G, De Munter G, McRae KB, Proudfoot FG. The effect of different totals and ratios of dietary calcium and phosphorus on the performance and incidence of leg abnormalities of male and female broiler chickens. Poult Sci. 1985;64(6):1157-69. https://doi.org/10.3382/ps. 0641157.

43. Momeneh T, Karimi A, Sadeghi G, Vaziry A, Bedford MR. Evaluation of dietary calcium level and source and phytase on growth performance, serum metabolites, and ileum mineral contents in broiler chicks fed adequate phosphorus diets from one to 28 days of age. Poult Sci. 2018; 97(4):1283-9. https://doi.org/10.3382/ps/pex432.
44. Hurwitz S, Fishman S, Talpaz H. Model of plasma calcium regulation: system oscillations induced by growth. Am J Phys. 1987;252(6):1173-81. https://doi. org/10.1152/ajpregu.1987.252.6.R1173.

45. Hurwitz S, Plavnik I, Shapiro A, Wax E, Talpaz H, Bar A. Calcium metabolism and requirements of chickens are affected by growth. J Nutr. 1995;125(10): 2679-86.

46. Shafey TM. Calcium tolerance of growing chickens: effect of ratio of dietary calcium to available phosphorus. World's Poult Sci J. 1993;49(1):5-18. https://doi.org/10.1079/WPS19930002.

47. Wilson JH, Mason JP. Bone breaking influenced by preconditioning. T ASAE. 1992;35(1):263-5. https://doi.org/10.13031/2013.28598.

48. Orban Jl, Adeola O, Stroshine R. Microbial phytase in finisher diets of white Pekin ducks: effect on growth performance, plasma phosphorus concentration, and leg bone characteristics. Poult Sci. 1999;78(3):366-77. https://doi.org/10.1093/ps/78.3.366.

49. Schreiweis MA, Orban JI, Ledur MC, Moody DE, Hester PY. Validation of dual-energy X-ray absorptiometry in live white leghorns. Poult Sci. 2005; 84(1):91-9. https://doi.org/10.1093/ps/84.1.91.

50. Angel R, Saylor WW, Mitchell AD, Powers W, Applegate TJ. Effect of dietary phosphorus, phytase and 25-hydroxycholecalciferol on broiler chicken bone mineralisation, litter phosphorus, and processing yields. Poul Sci. 2006;85(7): 1200-12. https://doi.org/10.1093/ps/85.7.1200.

51. Nizet A, Cavalier E, Stenvinkel P, Haarhaus M, Magnusson P. Bone alkaline phosphatase: an important biomarker in chronic kidney disease-mineral and bone disorder. Clin Chim Acta. 2020;501:198-206. https://doi.org/10.1016/j. cca.2019.11.012.

52. Tilagar V, Kilgas P, Viitak A, Reynolds SJ. The rate of bone mineralization in birds is directly related to alkaline phosphatase activity. Physiol Biochem Zool. 2008;81(1):106-11. https://doi.org/10.1086/523305.

53. Sarac F, Saygili F. Causes of high bone alkaline phosphatase. Biotechnol Biotechnol Equip. 2007;21 (2):194-7. https://doi.org/10.1080/13102818.2007.1 0817444.

54. Li T, Xing G, Shao Y, Zhang L, Li S, Lu L, et al. Dietary calcium or phosphorus deficiency impairs the bone development by regulating related calcium or phosphorus metabolic utilization parameters of broilers. Poult Sci. 2020;99(6):3207-14. https://doi.org/10.1016/.jpsj.2020. 01.028.

55. Xia WG, Zhang HX, Lin YC, Zheng CT. Evaluation of dietary calcium requirements for laying Longyan shelducks. Poult Sci. 2015;94(12):2932-7. https://doi.org/10.3382/ps/pev281.

56. Hurwitz $S$, Griminger P. The response of plasma alkaline phosphatase, parathyroids and blood and bone minerals to calcium intake in the fowl. J Nutr. 1961;73(2):177-85. https://doi.org/10.1093/jn/73.2.177.

57. Mehra A, Lee KH, Hatzimanikatis V. Insights into the relation between mRNA and protein expression patterns: I. Theor Considerations Biotechnol Bioeng. 2003;84(7):822-33. https://doi.org/10.1002/bit.10860.

58. Simonet WS, Lacey DL, Dunstan CR, Kelley M, Chang MS, Lüthy R, et al. Osteoprotegerin: a novel secreted protein involved in the regulation of bone density. Cell. 1997;89(2):309-19. https://doi.org/10.1016/S0092-8674 (00)80209-3.

59. Hauschka PV, Reid ML. Vitamin K dependence of a calcium-binding protein containing gamma-carboxyglutamic acid in chicken bone. J Biol Chem. 1978;253(24):9063-8. https://doi.org/10.1016/S0021-9258(1 7)34285-0.

60. Bergh JJ, Xu Y, Farach-Carson MC. Osteoprotegerin expression and secretion are regulated by calcium influx through the L-type voltage-sensitive calcium channel. Endocrinology. 2004;145(1):426-36. https://doi.org/10.1210/en.2 003-0319.

61. Liu R, Jin C, Wang Z, Wang Z, Wang J, Wang L. Effects of manganese deficiency on the microstructure of proximal tibia and opg/rankl gene expression in chicks. Vet Res Commun. 2015;39(1):31-7. https://doi.org/10.1 007/s11259-015-9626-5.

62. Hirata K, Tsukazaki T, Kadowaki A, Furukawa K, Shibata Y, Moriishi T, et al. Transplantation of skin fibroblasts expressing BMP-2 promotes bone repair more effectively than those expressing Runx2. Bone. 2003;32(5):502-12. https://doi.org/10.1016/S8756-3282(03)00054-1.

63. Jia Z, Wang S, He D, Cui L, Lu Y, Hu H, et al. Role of calcium in the regulation of bone morphogenetic protein 2, runt-related transcription factor 2 and Osterix in primary renal tubular epithelial cells by the vitamin $D$ receptor. Mol Med Rep. 2015;12(2):2082-8. https://doi.org/10.3892/mmr.201 5.3568. 
64. Zou L, Ji H, Liu Y, Song Y, Han H, Sun H, et al. Effects of dietary calcium levels on the bone morphogenetic protein-2 in blood and tibia performance of piglets. Feed Anim Husb. 2014;3:31-4.

65. Lu L, Zhang L, Li X, Zhang LY, Liao XD, Luo XG. Organic iron absorption by in situ ligated jejunal and ileal loops of broilers. J Anim Sci. 2018;96(12): 5198-208. https://doi.org/10.1093/jas/sky375.

66. Gautier $\mathrm{AE}$, Walk $\mathrm{CL}$, Dilger RN. Influence of dietary calcium concentrations and the calcium-to-non-phytate phosphorus ratio on growth performance bone characteristics, and digestibility in broilers. Poult Sci. 2017;96(8):2795803. https://doi.org/10.3382/ps/pex096.

Ready to submit your research? Choose BMC and benefit from:

- fast, convenient online submission

- thorough peer review by experienced researchers in your field

- rapid publication on acceptance

- support for research data, including large and complex data types

- gold Open Access which fosters wider collaboration and increased citations

- maximum visibility for your research: over $100 \mathrm{M}$ website views per year

At BMC, research is always in progress.

Learn more biomedcentral.com/submissions 